Volume and Issues Obtainable at Center for Sustainability Research and Consultancy

Journal of Business and Social Review in Emerging Economies

ISSN: 2519-089X \& ISSN (E): 2519-0326

Volume 8: Issue 1 March 2022

Journal homepage: www.publishing.globalcsrc.org/jbsee

\title{
Economic Violence against Women in Punjab: Dimensions, Determinants and its Implications on Women Social Status in Society
}

Dilshad Ahmad, Assistant Professor, Department of Management Sciences, COMSATS

University Islamabad, Vehari Campus, Pakistan

Salyha Zulfiqar Ali Shah, Assistant Professor, School of Economics, Bahauddin Zakariya

University Multan, Pakistan

Mah Rukh Shabbir, Ph.D. Scholar, Bahauddin Zakariya University Multan, Pakistan

*Corresponding author's email: salyhazulfiqar@bzu.edu.pk

\begin{tabular}{l}
\hline ARTICLE DETAILS \\
\hline History \\
Revised format: Feb 2022 \\
Available Online: Mar 2022 \\
\hline Keywords \\
Women Economic Violence, \\
Higher Education, Media, \\
Punjab, Pakistan
\end{tabular}

JEL Classification

$M 1, M 2$

\section{ABSTRACT}

Purpose: Women are almost half the population of the world while their poor social status and limited participation in society is a serious issue of their deprivation specifically in developing countries like Pakistan. This study was attempted to investigate economic violence against women and its influential factors on women's social status in society.

\section{Design/Methodology/Approach:}

The study used multiple regression analysis for empirical estimation of cross-sectional data of 840 married men from three low socio-economic districts Dera Ghazi Khan, Rajanpur and Muzaffargarh from Punjab province of Pakistan.

Findings: Empirical estimates of the study indicated among men above secondary school education, agricultural occupational status, emotional health status, childhood violence experience and witness are significant factors that impact women's economic violence.

\section{Implications/Originality/Value:}

There is a need for adequate legislation and policy measures for free and easy access to schooling, particularly in rural areas. In reducing gender disparity and violence's regarding women social media, electronic media and print media can play a significant role by providing productive and positive messages in discussions and programs.

(C) 2022 The authors, under a Creative Commons Attribution-

NonCommercial 4.0

Recommended citation: Ahmad, D., Shah, S. Z. A. and Shabbir, M. A. (2021). Economic Violence against Women in Punjab: Dimensions, Determinants and its Implications on Women Social Status in Society. Journal of Business and Social Review in Emerging Economies, 8 (1), $13-24$.

\section{Introduction}

"Achieve gender equality and empower all women and girls" is the $5^{\text {th }}$ Sustainable Development Goal (SDGs) which is generally persistent on empowering women with equal opportunity and 
authority in social, economic, political and public decisions of society (United Nations, 2015). In the Middle East and North Africa, the estimated gender gap was 39.8 percent while in South Asia 34.3 percent which is higher than the world scenario average of 32 percent (World Economic Forum (WEF), 2018). Political empowerment (77.1\%) and economic participation (41.9\%) were indicated higher sub-indexes status of gender gap disparity ratio while education attainment (4.4\%) and health care $(4.6 \%)$ with average lowest disparity ratio estimated (WEF, 2018). The significant representation of economic and social decisions regarding employment, health and education with zero discrimination prerequisite for fuelling sustainable development of economies and promoting the welfare of society (United Nations, 2015, Baig et al, 2017).

Behavioral practices not according to norms and the general sequence of society are indicated as violence ( Archavanichkul, 2006). Individual rights violations, limiting the private and public sphere of freedom of peoples, victims of mental and physical suffering inflictions elaborated as violence (National Human Rights Committee Office, 2009). Application of power or force to assault, to threat or offense other peoples, community or group of peoples with consequences of preventing potential human development, hearting feeling, death and injuries formally known as violence (World Health Organization, 2007). Reparation of property or lives due to some behaviors or act formally known as violence which is usually caused through the act of human being, accidental practices and natural forces without discrimination of age, gender, race and time. Children and women have indicated the significant victims of violence and men consider core origin (Sarkar, 2010). The extreme form of human rights violation and gender inequality is a violation against women and girls which leads to reducing earning and productivity and limits mobility and increases absenteeism from work (SERIES, 2018).

Economic, emotional, sexual and physical are some significant forms of women violations that are mostly practiced in homes, offices, educational institutions and public places (SERIES, 2018). Domestic violence affects women's livelihood and life is also known as economic violence which includes women's constraints no freedom of independent source of income, no freedom to work, stealing wife's money and limiting wives spending money (Ayuwat and Sananikone 2018). Constraints of access to adequate resources and lacking quality living major issues faced to victims of economic violence while it may be due to inadequate experience of women to managing money rather than their intimate partner (Howard and Skipp, 2015; National Assembly Committee on Women, 2011). The victims of economic violence generally face negative impacts regarding physical and psychological health issues in the shape of future financial uncertain stress and fear of poverty (Sanders, 2015; Smallwood, 2015). In the global scenario almost $35 \%$ of women facing the sexual or physical form of violence against intimate on non-intimate sexual partner according to the region of $37.7 \%$ in South-East Asia, 37\% in Eastern Mediterranean, 23.2\% in high income and 24.6\% Western Pacific countries (World Health Organization, 2017).

The estimated population of Pakistan is 207.77 million and women as 101.32 million which shares almost $49 \%$ population of the country (Pakistan Bureau of Statistics (PBS), 2017). Gender discrimination and social inequalities are major constraints in women's significant role in society and country (Patel, 2010). In South Asia, Pakistan was a higher ratio of gender bias and inequality about women (UNICEF, 2007). Pakistan in the current year 2018 was estimated the second-highest severe disparity status country followed by Yemen and ranked 148 out of 149 countries of the world regarding women disparity status also indicated an increasing disparity tendency related to the last year 2017 (WEF, 2018). In the world scenario average, 34\% managerial attainments of women were estimated while Pakistan is among the four worst status countries (Pakistan, Saudi Arabia, Egypt and Yemen) of the world with an average of less than $7 \%$ women managerial attainments (WEF, 2018). Social, cultural, demographic and economic constraints play a significant role in raising disparity status in developing countries like Pakistan. In Pakistan, women are less empowered, facing gender discrimination regarding social constraints and having limited 
participation status in the country (Government of Pakistan (GOP), 2018). The majority population almost $63.62 \%$ of the country inhabited in rural areas, out of $48 \%$ overall average literacy rate among females only $36 \%$ are literate in rural areas of Pakistan (Pakistan Social and Living Standards Measurement (PSLM), 2017; GOP, 2018). There are consecutive wide gender discrimination and rights violations regarding women employment opportunities, wages inequalities and frequent honor killing in rural areas.

Punjab is the most populated province of the country with an estimated population of 110 million and is the significance of $37 \%$ urban and $63 \%$ rural population (GOP, 2017). Lower literacy rate in rural areas male $(66 \%)$ and female $(44 \%)$ as compared to urban areas male $(82 \%)$ and female (73\%) was estimated in Punjab, Pakistan (Punjab Gender Parity Report (PGPR), 2018). Considerable women violations and miserable status in Punjab province have reported an increase in $5 \%$ of women violations (assaulting, rape, domestic violence, murder and honor killing) from 2016 to 2017 (PGPR, 2018). The objective of this study is to investigate the impact of male influential factors on women's economic violence in Punjab Pakistan. This research is categorized into five sections, the first section consists introduction of the study, literature review and theoretical framework highlighted in section two while material and methodology are discussed in section three. Results and discussion are illustrated in section four while the conclusion and suggestion are explained in the last section of this study.

\section{Theoretical Framework and Literature Review}

This study is based on intersectional theory which is rooted in the historical background of discrimination laws for African black women regarding critical race and black feminism theory as used by legal theorist African-American Kimberle Crenshaw (Monk, 2011; Viruell-Fuentes et al., 2012). The intersectional theory is included the international level with a significant approach of power structure and experiences of various sexual orientations, ethnicities and genders that can analyze contradictory trajectories of equality (Carbado et al., 2013). Political, representational and structural are three forms of intersectionality (Monk, 2011). In addressing the social problems faced by women related to investigating and outlined antiracist politics and feminist movements formally denoted the political intersectionality (Monk, 2011). Analyzing the women cultural issues those ignored and suppressed by leadership on basis of different form intersections nationality, ethnicity, age, gender, class and race known as representational intersectionality (Monk, 2011; Carastathis, 2014). Women's position of intersection is socially divided and affected by social division indicated the structural intersectionality (Monk, 2011). In Pakistan women mostly argued for vulnerable and disadvantaged political, civil, social and economic discrimination so this theory is compatibles with this research (Amnesty, 2002). Violence against women in Pakistan prominently related to rural/urban and classes as middle and upper urban areas women class face lower violence with more command on their lives related to schooling, health and employment access rather than rural women justify the intersectional theory (Ballantine et al., 2017). Domestic, social, cultural and economic violence are regarding women are also examples of gender discrimination in Pakistan (Iqbal et al., 2012). The conceptual framework of the study highlights the economic losses due to social and economic impacts of violence against women as indicated in figure 1. Negatively economic impacts through individual/household, community and government are determined due to violence against women. Violence against women causes negative impacts to cause social negative impacts through individuals/households, social cohesion and national as subsequently the economic losses. 
Figure 1 Conceptual Framework Social and Economic Impacts of Violation against Women

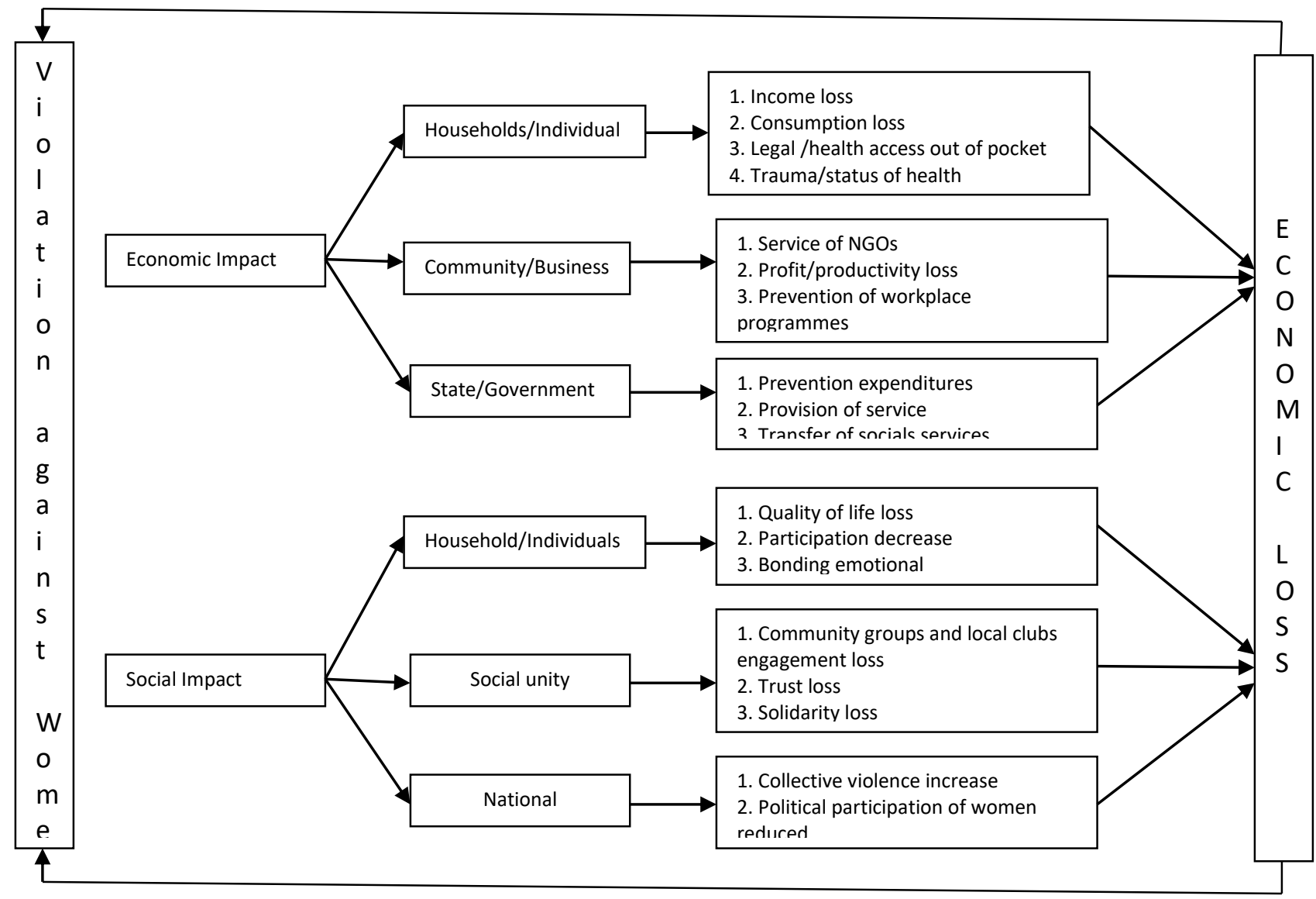

In literature regarding the historical scenario women were deprived of basic rights marriage choice, property, inheritance and children (Pakeeza, 2015) while due to the significant role of feminist activists now somehow the scenario has changed (Babur, 2007; United Nations, 2006; Qureshi, 2012; Khan, 2009) intensity and magnitude of abuses regarding women lives are still horrifying. Women throughout their lives face violence as the consensus of the community (Ali and Gavino, 2008; Heise et al., 1994; Saxena and Kumari, 2016). Former to birth with sex choosy abortion violence against women starts and continues till adulthood foremost to numberless pains and misery (United Nations, 2006). The studies of Coleman and Berenson, (2004) and Khan et al., (2013) elaborated in Pakistan there exists a skewed sex ratio as the reason of negligence is direct to death as indicates a higher infant mortality rate. Married women face a higher degree of sexual, psychological and physical violation from an intimate partner (United Nations, 2006; WHO, 2016) even also in old age due to some economic reasons forced homicide and suicide (Nosheen, 2011). Pakeeza (2015) the study highlighted the supremacy of men and dominance of women in cultural, social, economical and traditional scenarios regardless of significant legislation regarding women's rights. Galtung (1996) highlighted as gender inequality the root cause of cultural, structural and direct violence. Damaging and pains by punishing is denoted direct violence, working against weak and favoring powerful segment of society know as structural violence while reinforcing norms of structural and direct violence indicated as cultural violence's. Babur (2007) studied as in Pakistan women's status is deprived regarding the decisions choices of productive and reproductive, resources control, mobility and their behaviors with dominancy of male decisions. Karmaliani et al., (2012) in Pakistan the whole time society in all stage there is a common practice of women violence. Psychological context, political context, economic context, social and cultural contexts are major contributing factors regarding economic violence (United Nations, 2006). In the scenario of women's rights, these above-mentioned factors develop an unfavorable atmosphere whereas violence is used socially acknowledged with indicate of treat women unfavorably moving physical and mental health. Pakeeza, (2015) focused on Pakistan Shariah law application used to women 
rights which also determines the responsibility of State to ensure human rights protection for every individual while there remains the severe economic violence regarding women with the male dominant society. Qaisrani et al., (2016) tried to highlight the aspect of violence against women through socio-economic and cultural factors and find out that women face structural, cultural and direct violence's in Pakistan. Kabir and Khan (2019) study elaborated violence against women by an intimate partner and employment barriers in Armenia and conclude as women with an employed status fewer violations of rights rather than unemployed women. Rizvi and Feroz, (2019) focused the women's violence in the aspect of its prevalence and associated factors in Pakistan. This study highlighted the higher prevalence of women violence while major victims proportion not seeking help and not reported whereas higher affected women were those illiterate, unemployed and noncontraceptive uses due to illiterate life partner.

\section{Material and Methods}

Administratively Punjab province is categorized into nine divisions and thirty-six districts (Pakistan Bureau of Statistics, 2017). There were some significant reasons for the selection of the Punjab province region for this study. Firstly, Punjab province was purposively selected for the reason of the highest ratio of 74.96\% violence's against women (abduction, murder, honor killing, rape, sexual assault, domestic violence, etc) in the country (Aurat Foundation, 2014). Secondly, due to lower socioeconomic status and higher gender disparity ratio, these three districts Rajanpur, Dera Ghazi Khan and Muzaffargarh out of thirty-six districts of Punjab province based on the lowest economic, cultural and social progress index were specifically selected for the study (WEF, 2017; United Nations Development Programme (UNDP), 2017). According to Punjab's Social Progress Index 2015, district Dera Ghazi Khan, Rajanpur and Muzaffargarh have the lowest social (0.08) (0.35)(0.72), cultural (0.68)(0.76)(1.03), economic $(0.35)(0.54)(0.69)$ dimensions and social progress index $(0.13)(0.46)(0.66)$ comparative to rest of the districts of Punjab province (Government of Punjab, 2018).

Table 1: Punjab Province mostly Lagged behind Districts with Social Progress Index and Various Dimensions

\begin{tabular}{|l|l|l|l|l|l|}
\hline & Districts & Social dimension & $\begin{array}{l}\text { Cultural and gender } \\
\text { dimension }\end{array}$ & $\begin{array}{l}\text { Economic } \\
\text { dimension }\end{array}$ & $\begin{array}{l}\text { Index of social } \\
\text { progress }\end{array}$ \\
\hline 1 & Dera Ghazi Khan & 0.08 & 0.68 & 0.35 & 0.13 \\
\hline 2 & Rajanpur & 0.35 & 0.76 & 0.54 & 0.46 \\
\hline 3 & Muzaffargarh & 0.72 & 1.03 & 0.69 & 0.66 \\
\hline 4 & Rahim Yar Khan & 0.78 & 1.09 & 0.73 & 0.68 \\
\hline 5 & Bahawalpur & 0.75 & 1.04 & 0.70 & 0.67 \\
\hline 6 & Pakpattan & 0.56 & 0.99 & 0.60 & 0.62 \\
\hline 7 & Jhang & 0.86 & 1.14 & 0.77 & 0.82 \\
\hline 8 & Bhakkar & 0.99 & 1.25 & 0.80 & 0.91 \\
\hline
\end{tabular}

Sources; Punjab's Social Progress Index 2015

Lastly, rural areas were specifically focused in this study due to the prevalence of higher gender disparity and violence in rural areas in a contrast to urban areas and these districts Dera Ghazi Khan, Rajanpur and Muzaffargarh major population ratio $81 \%, 83 \%$ and $84 \%$ inhabited in rural areas (Government of Pakistan, 2017; PGRP, 2018).

The multistage simple random sampling approach was used for data collection procedures in the study area with different procedural steps. In the first stage, Punjab province was selected for study due to sharing $53.35 \%$ female population and sharing almost $75 \%$ acts of violence against women of the country (GOP, 2018). In the second stage, due to the highest ratio of gender disparity, lowest Multidimensional Poverty Index (MPI) and Human Development Index (HDI) districts of Punjab region Rajanpur, Dera Ghazi Khan and Muzaffargarh districts were specifically selected (WEF, 2017; UNDP, 2017; PRGP, 2018). 
Table 2: Lower HDI and MPI Districts in Punjab Province of Pakistan

\begin{tabular}{|l|l|l|l|}
\hline & Districts & $\begin{array}{l}\text { Human Development Index (HDI) } \\
(2015)\end{array}$ & $\begin{array}{l}\text { Multidirectional poverty index (MPI) value } \\
(2015)\end{array}$ \\
\hline 1 & Dera Ghazi Khan & 0.535 & 0.351 \\
\hline 2 & Rajanpur & 0.506 & 0.357 \\
\hline 3 & Muzaffargarh & 0.584 & 0.338 \\
\hline 4 & Rahim Yar Khan & 0.625 & 0.289 \\
\hline 5 & Bahawalpur & 0.645 & 0.272 \\
\hline 6 & Pakpattan & 0.660 & 0.189 \\
\hline 7 & Jhang & 0.682 & 0.196 \\
\hline 8 & Bhakkar & 0.628 & 0.255 \\
\hline
\end{tabular}

Sources; United Nations Development Program Report, 2017

Two tehsils from each district were selected due to the higher ratio of gender disparity and violations of women in the third stage (Punjab Commission on the Status of Women (PCSW), 2017). From each tehsil, two union councils were randomly selected in the fourth stage of the data collection procedure from the study area. Two villages from each union council were selected in the fifth stage of data collection. In the last stage, thirty-five married men respondent households from each village were selected as indicated in Table 3.

Table 3: Number of Affected and Selected Districts Union Councils, Villages, Household and Respondent

\begin{tabular}{|c|c|c|c|c|}
\hline Districts & Tehsil & Union Councils & Selected villages & No of respondents \\
\hline \multirow{8}{*}{ Dera Ghazi Khan } & Dera Ghazi Khan & Ghosa Abad & Chah Dadar Wala & 35 \\
\hline & & & Basti Lal Shah & 35 \\
\hline & & Basti Malana & Mud Bolo & 35 \\
\hline & & & Basti Mehran & 35 \\
\hline & Taunsa & Makwal Kallaan & Basti Mubarak Wali & 35 \\
\hline & & & Basti Makwal & 35 \\
\hline & & Hardan Sharqi & Basti Khosa & 35 \\
\hline & & & Basti Mahmood & 35 \\
\hline \multicolumn{4}{|c|}{ District Rahim Yar Khan total sample size } & 280 \\
\hline \multirow[t]{8}{*}{ Rajanpur } & Rajanpur & Kot Tahir & Rakh Azmat wala & 35 \\
\hline & & & Bastic shareefabad & 35 \\
\hline & & Hajipur & Basti Karya & 35 \\
\hline & & & Basti Mianwali & 35 \\
\hline & Rojhan & Kacha Mianwali & Meranpura village & 35 \\
\hline & & & Safdarabad & 35 \\
\hline & & Shah Wali & Basti Hameedabad & 35 \\
\hline & & & Basti Arz Muhammad & 35 \\
\hline \multicolumn{4}{|c|}{ District Rajanpur total sample size } & 280 \\
\hline \multirow[t]{8}{*}{ Muzaffargarh } & Kotaddu & Ahsan Pur & Bait Hinjranu village & 35 \\
\hline & & & Khara Niazi Wala & 35 \\
\hline & & Bat Qasim Wala & Khara Nawa & 35 \\
\hline & & & Tibbi Qarani & 35 \\
\hline & Alipur & Bait Mulan Wali & Malik Arian & 35 \\
\hline & & & Bait Channa & 35 \\
\hline & & Khan Garh Dooma & Missan & 35 \\
\hline & & & Kotla Ghulam Shah & 35 \\
\hline \multicolumn{4}{|c|}{ District Muzaffargarh total sample size } & 280 \\
\hline \multicolumn{4}{|c|}{ The total sample size of three districts } & 840 \\
\hline
\end{tabular}

Sources; authors collected data

This study used sample data of 840 married men and in sampling selection (Krejcie and Morgan, 1970) sampling table used for study areas and it collected from October 2017 to April 2018. A pretested and well-structured questionnaire was developed in the English language while it was translated into the Urdu language for ease of understanding and data collected from face-to-face meetings with the respondent in the national language Urdu or local language Punjabi and Saraiki for ease to understanding and proper response. Family and demographic characteristics, childhood 
witness violence, gender and violence perception, violence, law and policy perception, social and economic status, violence childhood experience and men's health status were some significant research tools used in the questioner for data collection.

In the econometric estimation linear regression model formally known as a starting point, The study used a multiple regression model for empirical estimation of the factors that significantly influence economic violence against women committed by the male population of the study area. Multiple Regression Analysis among one of the Multivariate Analysis techniques appropriately used in this study for identifying the factors to have a definite influence on common violence against women. In estimating data regarding Multiple Regression Analysis, data of both independent and dependent variables must be in ratio scale or interval scale. In the scenario of data is an ordinal level or nominal or lower than scale than dummy variable is developed before estimating through Multiple Regression Analysis. Avoiding the multicollinearity issued in relationship analysis, independent and dependent variables all pairs statistically tested for ensuring as no coefficient correlation value equal or more than 0.75 before using the Multiple Regression Analysis (Prasitratthasin, 1995). In the table of standard correlation coefficient the study variable pair of independent and dependent estimated values of correlation coefficient less than 0.75 indicating the possibility of application of Multiple Regression Analysis as used in some significant studies (Ayuwat and Sananikone, 2018) also employed in this study for empirical estimation.

\section{Results and Discussion}

In the total male sample population higher frequency of $40.05 \%$ of respondents were aged between 29-39 years while 30.47\% major proportion of the sample had below five years of schooling. The major proportion of study area population $79.63 \%$ employed in agriculture, $67.29 \%$ lower income status while having the lower emotional health status $28.15 \%$ and addiction of gambling $18.89 \%$. There was a limited level of awareness among married men regarding laws (12.73\%), sexuality $(9.35 \%)$ and violent acts $(7.11 \%)$. The major proportion of men $53.27 \%$ agreed as they pay for the bride so have more rights than women, $59.27 \%$ of men consensus to improve women violation laws so strict in current form and $67.91 \%$ of men stressed the need, women more obedient to husbands and current anti-violence activities cannot significantly impact in reducing the violence against women majority of men population $71.32 \%$ were in view. In childhood majority of men, $61.97 \%$ witnessed violence while limited community $13.87 \%$ were experienced their parent's verbal violence in the family some $15.29 \%$ experienced occasionally abuse violence while others $21.53 \%$ mostly faced physical violence in the family. Higher prevalence of economic violence $83.71 \%$ against wives by men was indicated in the study area, $13.79 \%$ of men accessed their wife income or assets without their permission, $32.85 \%$ of men generally use their wives' total income and higher men population $67.15 \%$ not willing to allow their wives to work outside home.

In estimating the Multiple Regression Analysis multivariate statistic test of dependent and independent variables all pairs estimated coefficient correlation less than 0.75 indicating as some significant independent variables emotional health, childhood witness of violence and childhood experience of violence influences the dependent variable as indicated in Table 4. Emotional health is the independent variable negative influential association with violence against women -1.437 indicating that a unit increase in the good emotional health of men will reduce the economic violence against women 1.437 unit. The positive association in the independent variable childhood witness violence 0.311 and economic violence against women elaborated as a unit increase in child witness violence will respond to increase in economic violence against women 0.311 . Independent variable childhood experience of violence has a positive relationship with economic violence against women as indicating one unit increase in childhood witness experience will increase 0.287 unit economic violence against women as indicated in table 4. Findings of emotional health, childhood violence witness and childhood violence experience regarding economic violence 
against women are similar to the study of (Ayuwat and Sananikone, 2018).

Table 4: Empirical Estimates of Influential Factors of Economic Violence against Women Perpetrated by Men in Punjab Pakistan

\begin{tabular}{|c|c|c|c|}
\hline Variables & $\mathrm{B}$ & Beta & $\mathrm{p}$-value \\
\hline Constant & 2.897 & & \\
\hline Age & -0.019 & -0.043 & 0.357 \\
\hline Illiterate & -0.187 & -0.137 & 0.298 \\
\hline Primary years of schooling & -0.211 & -1.491 & 0.453 \\
\hline Secondary years of schooling & -0.247 & -1.893 & 0.367 \\
\hline Above secondary years of schooling & -0.293 & -2.071 & 0.001 \\
\hline Occupational status (having agriculture) & 0.136 & 0.341 & 0.004 \\
\hline Income status yearly & -3.89 & -1.129 & 0.516 \\
\hline Emotional health & -1.437 & -1.879 & 0.009 \\
\hline Addiction of gambling & -0.128 & -0.138 & 0.317 \\
\hline Childhood violence experience & 0.287 & 0.359 & 0.002 \\
\hline Childhood violence witness & 0.311 & 0.421 & 0.013 \\
\hline Violence perception level & 0.123 & 0.139 & 0.237 \\
\hline Law perception level & 0.039 & 0.057 & 0.471 \\
\hline Gender perception level & 0.081 & 0.093 & 0.193 \\
\hline \multicolumn{2}{|l|}{ Model $\mathrm{R}^{2}$ value } & \multicolumn{2}{|c|}{0.397} \\
\hline \multicolumn{2}{|l|}{ F-statistics } & \multicolumn{2}{|c|}{5.142} \\
\hline
\end{tabular}

Empirical estimates of multiple regression model indicated as above secondary years of schooling, occupational status (agriculture), emotional health, childhood violence experience and witness were a more influential independent variable that impacts the dependent variable economic violence as indicated in table 4 . The positive and significant coefficient of agricultural occupational status of men (0.341), childhood violence experience (0.359) and childhood violence witness (0.421) indicate as one unit increase in agricultural occupational status, childhood violence experience and witness of childhood violence increase economic violence of women $0.341,0.359$ and 0.421 . In occupational status mostly illiterate or less educated men involved in agriculture relative to other occupations and indulged higher risk of crop earning so more stress and less education cause higher risk of economic violation regarding women and these results are in similar with the study of (Kutin et al., 2017). Economic violence increases with increasing childhood violence experience and witnesses it promotes in men's their supremacy psychology and women's restrictions like not allowing to work outside the home due to cultural constraints and involves women negative manners and various health issues and these findings are in line with the studies of (Benson et al, 2003; Fawole, 2008; Tolman and Rosen 2001; Ayuwat and Sananikone, 2018). The negative and significant coefficient of above secondary years of schooling (-2.071) and emotional health status (-1.879) elaborated as one unit increase in above higher secondary years of schooling and emotional health status it reduces the economic violence of women 2.071 and 1.879 unit. Higher education reduces economic violence of women the reason that literacy status positively promotes men's thinking as higher educated men relatively protect women rights, convinced zero gender discrimination and provide equal economic opportunities rather than illiterate or less educated men and these results are consistent with the study of (Kutin et al, 2017). Positive emotional health status reduces economic violence against women and sound health promotes positive emotional health status and these conclusions of the study are in line with the studies of (World Health Organization, 2007; Rocca et al, 2008; Ayuwat and Sananikone, 2018).

\section{Conclusion and Suggestions}

This study was attempted to identify the impact of male influential factors on women's economic violence in low socio-economic districts of Punjab Pakistan. In the empirical estimation of the study, above secondary years of schooling, the agricultural status of occupation, emotional health status, childhood violence experience and witnessing were some significant factors that influence economic violence against women in the study. Increasing status of above secondary years of 
schooling and sound emotional health status among men reduces women economic violation while increasing agricultural occupational status, childhood violence experience and witnessing among men increases women economic violence. In the current scenario of increasing gender disparity and women's economic violence generally in developing countries like Pakistan, there is a need for some significant policy measures to empower women. There is a need to increase the literacy ratio among the population for free and easy access by implementing proper educational policies measures. In rural areas farming community mostly remains depressed due to their risky scenario of agriculture and causes acts of violence's so there is a need to be sound policy measures regarding agricultural risk protection of the farming community. Women violence scenario in social family structure can be addressed at family level by upbringing children to prevent violence thinking and providing violence-free friendly environment in the family and society basis. Media (electronic, print and social) can play a significant role in reducing gender disparity and violence's regarding women through providing productive and positive discussions and programs.

\section{References}

Ali, P. A., \& Gavino, M. I. B. (2008). Violence against women in Pakistan: A framework for analysis. Journal-Pakistan Medical Association, 58(4), 198.

Amnesty International. (2002). Pakistan: Insufficient protection of women. Karachi: Amnesty International.

Archavanichkul, K. (2006). Politics on sex and women's body. AIDS and Sexuality in Thai Society, 5(1), 269-399.

1) Aurat Foundation (2014). "Violence against women in Pakistan A qualitative review of reported incidents" Violence Against Women Annual Report 2014. https://www.af.org.pk/PDF/VAW\%20Reports\%20AND\%20PR/VAW\%202014.pdf

Ayuwat, D., \& Sananikone, S. (2018). Influential Factors Among Male Population, Which Associated with the Economic Violence Against Women in Laos. Gender Issues, 35(4), 330-338.

Babur, Z. U. (2007). Violence Against Women in Pakistan: Current realities and strategies for change. Unpublished MA Thesis. European University Center for Peace Studies.

Baig, I. A., Batool, Z., Ali, A., Baig, S. A., Hashim, M., \& Zia-ur-Rehman, M. (2017). Impact of women empowerment on rural development in Southern Punjab, Pakistan. Quality \& Quantity, 1-12 https://doi.org/10.1007/s11135-017-0572-x

Ballantine, C. et al., (2017), Working Paper No.5 - Pakistan: The Economic and Social Impact of Violence Against Women and Girls (VAWG), UK aid

Benson, M. L., Fox, G. L., DeMaris, A., \& Van Wyk, J. (2003). Neighborhood disadvantage, individual economic distress and violence against women in intimate relationships. Journal of quantitative criminology, 19(3), 207-235.

Carastathis, A. (2014). The concept of intersectionality in feminist theory. Philosophy Compass, 9(5), 304-314.

Carbado, D. W., Crenshaw, K. W., Mays, V. M., \& Tomlinson, B. (2013). Intersectionality: Mapping the movements of a theory. Du Bois review: social science research on race, $10(2), 303-312$.

Coleman, E. A., \& Berenson, R. A. (2004). Lost in transition: challenges and opportunities for improving the quality of transitional care. Annals of internal medicine, 141(7), 533-536.

Fawole, O. I. (2008). Economic violence to women and girls: is it receiving the necessary attention?. Trauma, Violence, \& Abuse, 9(3), 167-177.

Galtung, J. (1996). Peace by peaceful means: Peace and conflict, development and civilization (Vol. 14). Sage.

Government of Pakistan (2017). Economic survey of Pakistan 2016-17, Pakistan Bureau of Statistics Ministry of Finance Government of Pakistan (GOP).

Government of Punjab, (2018). Punjab's Social Progress Index 2015, A District Level Analysis, Analysis Paper Urban Unit, Lahore Punjab, Pakistan 
https://www.weforum.org/reports/the-global-gender-gap-report-2018

Government of Pakistan (2018). Economic survey of Pakistan 2017-18, Pakistan Bureau of Statistics Ministry of Finance Government of Pakistan (GOP).

Heise, L., Heise, L. L., Pitanguy, J., \& Drouin-Germain, A. (1994). Violence Against Women: The Hidden Health Burden. World Bank Discussion Paper.

Howard and Skipp (2015). Unequal, Trapped and Controlled: Women's Experience of Financial Abuse and Potential Implications for Universal Credit. TUC, Women's Aid Federation of England.

Iqbal, H., Afzal, S., \& Inayat, M. (2012). Gender Discrimination: Implications for Pakistan Security. IOSR Journal of Humanities and Social Science, 1(4), 16-25.

Kabir, R., \& Khan, H. T. (2019). A cross-sectional study to explore intimate partner violence and barriers to empowerment of women in Armenia. BioMed research international, 2019.

Karmaliani, PhD, R., Pasha, MA, A., Hirani, MScN, S., Somani, MScN, R., Hirani, MScN, S., Asad, N., ... \& McFarlane, DrPH, FAAN, J. (2012). Violence against women in Pakistan: contributing factors and new interventions. Issues in mental health nursing, 33(12), 820826.

Khan, H. M. A., Sindher, R. H. K., \& Hussain, I. (2013). Studying the role of education in eliminating violence against women. Pakistan Journal of Commerce and Social Sciences (PJCSS), 7(2), 405-416.

Khan, R. (2009). Situational Analysis and Mapping of Women's Human Rights in Pakistan. Report Gender Equity Program (GEP) USAID/Aurat Foundation http://www. state. gov/g/drl/rls/hrrpt/2009/sca/136092/htm Retrieved on, 2(05), 2014.

Krejcie, R. V., \& Morgan, D. W. (1970). Determining sample size for research activities. Educational and psychological measurement, 30(3), 607-610.

Kutin, J., Russell, R., \& Reid, M. (2017). Economic abuse between intimate partners in Australia: prevalence, health status, disability and financial stress. Australian and New Zealand journal of public health, 41(3), 269-274.

Monk, H. L. (2011). Understanding Sexed and Racialised Violence: An Intersectional Approach (Doctoral dissertation, University of Central Lancashire).

National Assembly Committee on Women (2011). Violence: Guidelines and policy for the prevention of violence. The National Assembly Committee on Women, Youth, and the Elderly Bangkok: Ministry of Social Development and Human Security.

National Human Rights Committee Office (2009). The Promotion and Coordination Office of the National Women Committee. (2009). Rights and freedom to life and body. Bangkok: National Human Rights Committee Office.

Nosheen, H. (2011). Violence against women. The Dialogue, 6(3). Development Administration.

Pakeeza, S. (2015). Domestic violence laws and practices in Pakistan. VFAST Transactions on Education and Social Sciences, 6(1).

Pakistan Bureau of Statistics (2017). $6^{\text {th }}$ population and Housing Census, Pakistan Bureau of statistics Ministry of Finance, Government of Pakistan.

Patel, R. (2010). Gender equality and women's empowerment in Pakistan. Oxford University Press.

PCSW, (2017). Punjab Commission on the Status of Women (PCSW), 2017, Annual Report 2016 Government of Punjab, Pakistan

2) PGPR, (2018). Punjab Gender Parity Report (PGPR) 2018. PUNJAB COMMISSION ON THE STATUS OF WOMEN, Government of Punjab, Pakistan.

https://pcsw.punjab.gov.pk/system/files/PGPR-2018_0.pdf

Prasitratthasin, S. (1995). Social sciences research methodology. Bangkok: National Institute of

PSLM (2017). Pakistan Social and Living Standard Measurement 2016-17 Economic Survey of Pakistan, Pakistan Bureau of Statistics Ministry of Finance, Government of Pakistan (GOP).

Qaisrani, A., Liaquat, S., \& Khokhar, E. N. (2016). Socio-economic and cultural factors of 
violence against women in Pakistan.

Qureshi, S. (2012). Legislative initiative in the area of domestic violence in Pakistan: Gender approach to the core provisions of the Domestic Violence (Prevention and Protection) Act 2009. Pakistan Vision, 13(2), 200.

Rizvi, N., \& Feroz, A. (2019). Prevalence and Factors Associated with Violence against Women in Pakistan. Journal of Women's Health and Gynecology, 1(1), 1.

Rocca, C. H., Rathod, S., Falle, T., Pande, R. P., \& Krishnan, S. (2008). Challenging assumptions about women's empowerment: social and economic resources and domestic violence among young married women in urban South India. International journal of epidemiology, 38(2), 577-585.

Sarkar, M. (2010). A study on domestic violence against adult and adolescent females in a rural area of West Bengal. Indian journal of community medicine: official publication of Indian Association of Preventive \& Social Medicine, 35(2), 311.

Sanders, C. K. (2015). Economic abuse in the lives of women abused by an intimate partner: A qualitative study. Violence against women, 21(1), 3-29.

Saxena, S., \& Kumari, S. (2016). Violence against Women: An Analysis. Samwaad: EJournal, 5(1), 50-60.

SERIES, B. T. T. (2018). GLOBAL AND REGIONAL TRENDS IN WOMEN'S LEGAL PROTECTION AGAINST DOMESTIC VIOLENCE AND SEXUAL HARASSMENT. pubdocs.worldbank.org/.../EndingViolenceAgainstWomenandGirls-GBVLaws-Feb20...

Smallwood, E. (2015). Stepping stones: legal barriers to economic equality after family violence.

Tolman, R. M., \& Rosen, D. (2001). Domestic violence in the lives of women receiving welfare: Mental health, substance dependence, and economic well-being. Violence against women, 7(2), 141-158.

United Nations. (2006). Ending Violence Against Women: From Words to Action. Geneva: UN.

United Nations (2015). Sustainable Development Goals, 2015, United Nations https://www.un.org/sustainabledevelopment/development-agenda/

United Nation Development Programme, (2017). "Pakistan Human Development Index Report 2017" United Nations Development Programme (UNDP), Pakistan, Islamabad, Pakistan

UNICEF, (2007). The state of the world's children 2007, Women and Children The Double Dividend of Gender Equality, United Nations International Children's Emergency Fund (UNICEF), New York, USA. https://www.unicef.org/publications/files/The_State_of the Worlds_Children_2007_e. pdf

Viruell-Fuentes, E. A., Miranda, P. Y., \& Abdulrahim, S. (2012). More than culture: structural racism, intersectionality theory, and immigrant health. Social science \& medicine, 75(12), 2099-2106.

World Economic Forum (2018). The Global Gender Gap Report 2018, World Economic Forum, Org, Switzerland

World Health Organization. (2007). World report on violence and health. Geneva: WHO.

World Health Organization. (2016). Ethical and safety recommendations for intervention research on violence against women: building on lessons from the WHO publication putting women first: ethical and safety recommendations for research on domestic violence against women.

World Health Organization (2017). "Violence against women" Fact sheet, World Health Organization, 201 7. https://www.who.int/news-room/fact-sheets/detail/violence-against$\underline{\text { women }}$ 
